Volume 1 Nomor 1, November 2020: h. 14 - 23

P-ISSN: 2722-4465, E-ISSN: 2746-8151

Creative Commons Attribution-NonCommercial 4.0 International

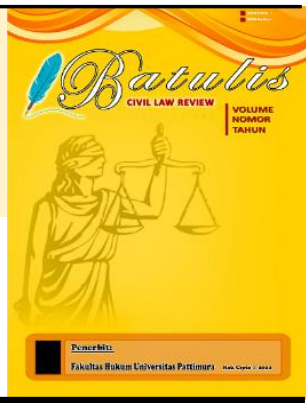

\title{
Kajian Kritis Terhadap Dualisme Pengadilan Elektronik (E-Court) dan Konvensional
}

\author{
Khotib Iqbal Hidayat ${ }^{1}$, Aris Priyadi ${ }^{2}$, Elly Kristiani Purwendah ${ }^{3 \star}$ \\ 1,2,3 Fakultas Hukum Universitas Wijayakusuma Purwokerto, Purwokerto, Indonesia. \\ *E-mail: elly_kristiani@yahoo.co.id
}

\begin{tabular}{|c|c|}
\hline Dikirim: 04/06/2020 & Dipublikasi: 30/10/2020 \\
\hline Info Artikel & Abstract \\
\hline \multirow[t]{2}{*}{$\begin{array}{l}\text { Keywords: } \\
\text { Electronics Justice System } \\
\text { (e-Court); Law of Civil } \\
\text { Procedure; Court Dualism }\end{array}$} & $\begin{array}{l}\text { This study aims to determine how the application of electronisc justice } \\
\text { system (e-Court) in providing the principle of benefit for the parties in } \\
\text { civil cases. This study uses a normative juridical approach with } \\
\text { secondary data sources supported by primary data. The results showed } \\
\text { that the existence of electronisc justice system (e-Court) can provide the } \\
\text { principle of benefit for the parties including transparency of the process, } \\
\text { cost, and time efficiency for justice seekers who are able to access IT } \\
\text { (Information Technology) and the existence of dualism is still needed } \\
\text { for justice seekers which still requires conventional proceedings due to } \\
\text { limited access to IT (Information Technology). }\end{array}$ \\
\hline & Abstrak \\
\hline $\begin{array}{l}\text { Kata Kunci: } \\
\text { Pengadilan Elektronik; } \\
\text { Hukum Acara Perdata; } \\
\text { Dualisme Pengadilan }\end{array}$ & $\begin{array}{l}\text { Penelitian ini bertujuan untuk mengetahui bagaimanakah penerapan } \\
\text { pengadilan elektronik (e-Court) dalam memberi asas kemanfaatan bagi } \\
\text { para pihak dalam perkara perdata. Penelitian ini menggunakan metode } \\
\text { pendekatan yuridis normatif dengan sumber data sekunder di dukung } \\
\text { data primer. Hasil penelitian menunjukkan bahwa adanya pengadilan } \\
\text { secara elektronik (e-Court) dapat memberikan asas kemanfaatan bagi } \\
\text { para pihak meliputi transparasi proses, biaya, dan efisiensi waktu bagi } \\
\text { para pencari keadilan yang mampu mengakses IT (Information } \\
\text { Technology) serta adanya dualisme masih dibutuhkan bagi para } \\
\text { pencari keadilan yang masih membutuhkan beracara secara }\end{array}$ \\
\hline $\begin{array}{l}\text { DOI: } \\
\text { 10.47268/ballrev.v1i1.421 }\end{array}$ & $\begin{array}{l}\text { konvensional karena keterbatasan mengakses IT (Information } \\
\text { Technology). }\end{array}$ \\
\hline
\end{tabular}

\section{Pendahuluan}

Dalam pelaksanaan hukum materiil, khususnya hukum materiil perdata diperlukan peraturan hukum yang diperuntukkan menjamin ditaatinya hukum materiil perdata yaitu hukum formiil atau hukum acara perdata. Saat ini pengaturan tentang cara menyelesaikan perkara hukum perdata melalui pengadilan masih didasarkan pada peraturan-peraturan yang merupakan produk pemerintahan kolonial Belanda, meskipun sudah terdapat juga beberapa produk nasional tentang cara berperkara ke pengadilan yang tersebar secara parsial, karena sampai saat ini hukum acara perdata yang berlaku di Indonesia masih bersifat plurarisme (Fakhriah, 2019: 1). Hukum materiil perdata pada dasarnya mengutamakan kepentingan privat masing-masing pihak dalam berperkara, sehinga untuk 
mewujudkan peraturan hukum yang sesuai dengan tujuan hukum (Idee des Recht) yang meliputi kepastian hukum (rechtssicherkeit), keadilan (gerechtigkeit) dan kemanfaatan (zweckmasigkeit), maka kemanfaatan dalam hukum formiil perdata harus terpenuhi.

Pemenuhan kemanfaatan pada hukum acara perdata sudah menjadi kewajiban seorang hakim selaku penegak hukum yang memiliki kekuasaan kehakiman. Kekuasaan kehakiman merupakan kekuasaan yang merdeka untuk menyelenggarakan peradilan guna menegakkan hukum dan keadilan, penegasan tersebut terdapat juga dalam UndangUndang Kekuasaan Kehakiman yang mengatur bahwa kekuasaan kehakiman adalah kekuasaan negara yang merdeka untuk menyelenggarakan peradilan guna menegakkan hukum dan keadilan berdasarkan Pancasila demi terselenggaranya Negara hukum Republik Indonesia (Wantu, 2012: 481). Hakim yang mencerminkan kemanfaatan dalam putusannya manakala hakim tidak saja menerapkan hukum secara tekstual belaka dan hanya mengejar keadilan semata, akan tetapi juga mengarahkan pada kemanfaatan bagi kepentingan pihakpihak yang berperkara dan kepentingan masyarakat pada umumnya (Wantu, 2012: 485).

Pasal 2 ayat (4) Undang-Undang Nomor 48 tahun 2009 tentang Kekuasaan Kehakiman mengemukakan bahwa era modern ini pelaksanaan peradilan di Indonesia telah mengalami perkembangan mengikuti asas penyelenggaraan peradilan di Indonesia. Penyelenggaraan peradilan di Indonesia didasarkan pada asas sederhana, cepat dan biaya ringan. Guna menerapkan asas tersebut Mahkamah Agung membuat kebijakan mengenai administrasi perkara dan persidangan di pengadilan secara elektronik yang tertuang dalam Peraturan Mahkamah Agung (PERMA) Nomor 1 Tahun 2019. Penerapan Peraturan Mahkamah Agung (PERMA) Nomor 1 Tahun 2019 tentang Administrasi Perkara Dan Persidangan Di Pengadilan Secara Elektronik tentunya harus memiliki asas kepastian hukum. Kepastian hukum dapat dimaknakan bahwa seseorang akan dapat memperoleh sesuatu yang diharapkan dalam keadaan tertentu. Kepastian diartikan sebagai kejelasan norma sehingga dapat dijadikan pedoman bagi masyarakat yang dikenakan peraturan ini. Hukum bertugas menciptakan kepastian hukum karena bertujuan untuk menciptakan ketertiban dalam masyarakat. Kepastian hukum merupakan ciri yang tidak dapat dipisahkan dari hukum terutama norma hukum tertulis. Hukum tanpa nilai kepastian hukum akan kehilangan makna karena tidak lagi dapat dijadikan pedoman perilaku bagi semua orang (Wijayanta, 2014: 220).

Proses penyelesaian perkara di persidangan tidak selalu dilakukan dengan cara konvensional yakni para pihak secara langsung datang ke persidangan akan tetapi dapat dilakukan secara online. Hal ini ditandai dengan diluncurkannya aplikasi e-court pada tanggal 13 Juli 2018 (Retnaningsih, S., et al., 2020: 124). Pengadilan elektronik (e-Court) adalah layanan bagi Pengguna Terdaftar untuk Pendaftaran Perkara Secara Online, Mendapatkan Taksiran Panjar Biaya Perkara secara online, Pembayaran secara online, Pemanggilan yang dilakukan dengan saluran elektronik, dan Persidangan yang dilakukan secara elektronik. Adapun fitur yang tersedia adalah $e$-Filing (Pendaftaran Perkara Online di Pengadilan), $e$ Payment (Pembayaran Panjar Biaya Perkara Online), e-Summons (Pemanggilan Pihak secara online), e-Litigation (Persidangan secara online) (Mahkama Agung RI, n.d.).

Minimnya penerapan e-litigation ini berbanding lurus dengan peraturan yang mengatur tentang e-litigation itu sendiri. Berdasarkan penelusuran yang dilakukan oleh Penulis, peraturan yang mengatur tentang e-litigation hanya ada di Perma Nomor 1 Tahun 2020 dan SEMA Nomor 1 Tahun 2020. Bahkan Surat Edaran Mahkamah Agung RI Nomor 4 Tahun 2020 tentang perubahan SE MA Nomor 1 Tahun 2020, tidak mengatur atau menyebutkan perihal eLitigation (Lumbanraja, 2020: 51). 
Sistem informasi $e$-Court telah melaksanakan pengadministrasian suatu perkara secara memadai, meski demikian keberadaan administrasi perkara secara konvensional masih dipertahankan karena Peradilan secara elektronik yang dilaksanakan pada saat ini adalah Peradilan secara elektronik sebagian, sehingga tidak semua tahapan pemeriksaan perkara dilaksanakan secara elektronik (Sudarsono, 2019: 55).

Perkembangan ini membuat hakim dalam menerima dan menyelesaikan perkara perdata dapat dilakukan dalam dua cara, yaitu secara konvensional dan elektronik. Setelah melihat latar belakang masalah di atas, maka dapat dirumuskan permasalahan sebagai berikut, "Bagaimanakah penerapan pengadilan elektronik (e-Court) dalam memberi asas kemanfaatan bagi para pihak dalam perkara perdata ?".

\section{Metode Penelitian}

Penelitian ini menggunakan metode pendekatan yuridis normatif dengan sumber data sekunder di dukung data primer. Data primer berupa penelusuran / pengamatan diperlukan terhadap pengguna pengadilan elektronik (e-Court), dilakukan / diakses melalui penelusuran / pengamatan dari internet dan data sekunder sebagai data pendukung berupa bahan-bahan hukum. Penelitian ini bertujuan untuk mengetahui bagaimanakah penerapan pengadilan elektronik (e-Court) dalam memberi asas kemanfaatan bagi para pihak dalam perkara perdata. Spesifikasi teknik deskriptif analitis yaitu mengungkapkan peraturan perundang-undangan yang berkaitan dengan teori-teori hukum yang menjadi objek penelitian. Demikian juga hukum dalam pelaksanaanya di dalam masyarakat yang berkenaan dengan objek penelitian (Ali, 2016: 106).

\section{Hasil dan Pembahasan}

\subsection{Pengadilan Elektronik (e-Court)}

Dalam melaksanakan persidangan secara elektronik maka pihak-pihak yang berperkara harus menjadi pengguna terdaftar dan mengikuti langkah-langkah berikut dalam melaksanakan e-Court berdasarkan buku panduan e-Court 2019 dari Mahkamah Agung:

a) Pendaftaran Perkara Pengguna Terdaftar (Advokat)

Sebelum melakukan pendaftaran syarat wajib yang harus dilakukan adalah harus memiliki akun pada aplikasi $e$-Court. Untuk melakukan pendaftaran melalui $e$-Court yang dilakukan pertama kali adalah membuka website e-Court MA di https://ecourt.mahkamahagung.go.id dan menekan tombol Register Pengguna Terdaftar.

b) Login

Login pada aplikasi $e$-Court dapat dilakukan pada tombol Login halaman pertama e-Court. Setelah berhasil login untuk pertama kali login, pengguna terdaftar harus melengkapi data Advokat. Pengguna Terdaftar untuk saat ini bisa dilakukan oleh Advokat, tetapi untuk pengguna terdaftar lain dari Perseorangan, Pemerintah atau Badan Hukum sudah bisa juga mengakses $e$-Court dengan melakukan pendaftaran melalui datang ke pengadilan. Dalam melengkapi Data Advokat juga jarus melengkapi dengan dokumen Advokat sesuai persyaratan yang telah diatur pada Perma No. 1 Tahun 2019 yaitu KTP, Berita Acara Sumpah dan Kartu Tanda Anggota (KTA). Dengan melengkapi data Advokat yang benar untuk pendaftaran akun pengguna terdaftar telah selesai dilakukan, akan tetapi untuk bisa beracara dengan 
menggunakan $e$-Court harus menunggu verifikasi dan validasi oleh Pengadilan Tingkat Banding dimana Advokat tersebut disumpah.

c) Pendaftaran Perkara

Tahapan Pendaftaran Perkara melalui e-Court sebagai berikut :

1) Memilih Pengadilan

Pengguna terpilih (advokat) memilih menu dari Pendaftaran Perkara dan memilih sesuai dengan kebutuhan jenis perkara yaitu Gugatan Online, Bantahan Online, Gugatan Sederhana Online, dan Permohonan Online. Apabila advokat sudah memilih jenis perkara yang didaftarkan maka selanjutnya pilih Tambah Gugatan. Ketika pengguna ingin menambakan perkara sesuai dengan jenisnya, pengguna memilih pengadilan tujuan untuk mendaftarkan perkaranya.

\section{2) Mendapatkan Nomor Register Online (Bukan Nomor Perkara)}

Pada tahapan awal, setelah memilih Pengadilan pengguna terdaftar akan mendapatkan Nomor Register Online dan Barcode akan tetapi bukan Nomor Perkara. Setelah memahami dan menyetujui syarat dan ketentuan dalam pendaftaran online melalui $e$-Court, tekan Tombol Daftar.

3) Pendaftaran Kuasa

Pendaftaran Surat Kuasa adalah bagian dari tahapan dimana Advokat atau Pengguna terdaftar harus mengupload Surat Kuasa sebelum melanjutkan pendaftaran perkara.

4) Mengisi Data Pihak

Mengisi Data Pihak adalah menjadi hal wajib dalam pendaftaran perkara dan dalam pengisian data pihak ini akan mengisi alamat pihak baik penggugat, tergugat, dan turut tergugat sehingga dapat memilih lokasi Provinsi, Kabupaten dan Kecamatan. Dengan melengkapi data alamat maka biaya panjar dapat ditaksirkan sesuai besaran radius masing-masing wilayah pengadilan sesuai ketetapan Ketua Pengadilan. Pengguna selanjutnya menambahkan data pihak yang berperkara yaitu Penggugat, Tergugat dan Turut Tergugat (jika ada).

5) Upload Berkas Gugatan

Tahapan berikutnya adalah melengkapi Dokumen Gugatan yang harus diupload pada tahapan Upload Berkas. Berkas Gugatan dan Persetujuan Prinsipal diupload dalam tahapan Upload Berkas Gugatan.

6) Elektronik SKUM (e-SKUM)

Dengan selesainya melengkapi data pendaftaran dan dokumen Pengguna Terdaftar akan mendapatkan taksiran panjar biaya perkara dalam bentuk Elektronik SKUM (e-SKUM) yang digenerate otomatis oleh sistem dengan Komponen Biaya Panjar dan Radius yang telah ditetapkan oleh Ketua Pengadilan. Ketika Pengguna telah mendapatkan e-SKUM untuk melakukan pembayarannya, selanjutnya user memilih tombol 'Lanjut Pembayaran'. 


\section{7) Pembayaran (e-Payment)}

Pengguna Terdaftar setelah mendapatkan Taksiran Panjar atau e-SKUM akan mendapatkan Nomor Pembayaran (Virtual Account) sebagai rekening virtual untuk pembayaran Biaya Panjar Perkara.

8) Mendapatkan Nomor Perkara

Pengadilan baru akan mendapatkan notifikasi atau pemberitahuan disaat Pendaftaran Perkara sudah dilakukan pembayaran kemudian Pengadilan akan melakukan verifikasi dan validasi dilanjutkan dengan mendaftarkan Perkara di SIPP (Sistem Informasi Penelusuran Perkara) yang merupakan aplikasi manajemen administrasi perkara di Pengadilan sehingga akan otomatis mendapatkan Nomor Perkara dan melalui SIPP akan otomatis mengirimkan informasi pendaftaran perkara berhasil melalui $e$-Court dan SIPP.

9) Mendapatkan Panggilan Elektronik (e-Summons)

Setelah pengguna melakukan pembayaran dan mendapat nomor perkara dari yang telah didaftarkan tersebut maka akan mendapat sebuah panggilan persidangan yang dikirim oleh pihak pengadilan tempat pendaftaran perkara.

10) Persidangan Elektronik (e-Ligitation)

Pada e-Ligitation ini acara persidangan secara Elektronik oleh para pihak dimulai dari acara Jawaban, Replik, Duplik dan Kesimpulan.

\subsection{Pengadilan Konvensional}

\subsubsection{Proses Pendaftaran Perkara Perdata}

1) Pihak berperkara datang ke Pengadilan Negeri dengan membawa surat gugatan atau permohonan.

2) Pihak berperkara menghadap petugas Meja Pertama dan menyerahkan surat gugatan atau permohonan, 4 (empat) rangkap. Untuk surat gugatan ditambah sejumlah Tergugat.

3) Petugas Meja Pertama (dapat) memberikan penjelasan yang dianggap perlu berkenaan dengan perkara yang diajukan dan menaksir panjar biaya perkara yang kemudian ditulis dalam Surat Kuasa Untuk Membayar (SKUM).

4) Petugas Meja Pertama menyerahkan kembali surat gugatan atau permohonan kepada pihak berperkara disertai dengan Surat Kuasa Untuk Membayar (SKUM) dalam rangkap 3 (tiga).

5) Pihak berperkara menyerahkan kepada pemegang kas (KASIR) surat gugatan atau permohonan tersebut dan Surat Kuasa Untuk Membayar (SKUM).

6) Pemegang kas menyerahkan asli Surat Kuasa Untuk Membayar (SKUM) kepada pihak berperkara sebagai dasar penyetoran panjar biaya perkara ke bank.

7) Pihak berperkara datang ke loket layanan bank dan mengisi slip penyetoran panjar biaya perkara. Pengisian data dalam slip bank tersebut sesuai dengan Surat Kuasa Untuk Membayar (SKUM), seperti nomor urut, dan besarnya biaya penyetoran. 
Kemudian pihak berperkara menyerahkan slip bank yang telah diisi dan menyetorkan uang sebesar yang tertera dalam slip bank tersebut.

8) Setelah pihak berperkara menerima slip bank yang telah divalidasi dari petugas layanan bank, pihak berperkara menunjukkan slip bank tersebut dan menyerahkan Surat Kuasa Untuk Membayar (SKUM) kepada pemegang kas.

9) Pemegang kas setelah meneliti slip bank kemudian menyerahkan kembali kepada pihak berperkara. Pemegang kas kemudian memberi tanda lunas dalam Surat Kuasa Untuk Membayar (SKUM) dan menyerahkan kembali kepada pihak berperkara asli dan tindasan pertama Surat Kuasa Untuk Membayar (SKUM) serta surat gugatan atau permohonan yang bersangkutan.

10) Pihak berperkara menyerahkan kepada petugas Meja Kedua surat gugatan atau permohonan sebanyak jumlah tergugat ditambah 2 (dua) rangkap serta tindasan pertama Surat Kuasa Untuk Membayar (SKUM).

11) Petugas Meja Kedua mendaftar/mencatat surat gugatan atau permohonan dalam register bersangkutan serta memberi nomor register pada surat gugatan atau permohonan tersebut yang diambil dari nomor pendaftaran yang diberikan oleh pemegang kas.

12) Petugas Meja Kedua menyerahkan kembali 1 (satu) rangkap surat gugatan atau permohonan yang telah diberi nomor register kepada pihak berperkara.

13) Pendaftaran Selesai

14) Pihak / pihak-pihak berperkara akan dipanggil oleh jurusita / jurusita pengganti untuk menghadap ke persidangan setelah ditetapkan Susunan Majelis Hakim $(\mathrm{PMH})$ dan hari sidang pemeriksaan perkaranya (PHS) (Pengadilan Negeri Ungaran, n.d.).

\subsubsection{Proses Persidangan Perkara Perdata Secara Konvensional}

Setelah gugatan diajukan dan didaftarkan oleh panitera dalam suatu daftar untuk diperiksa dalam sidang, maka Ketua Pengadilan Negeri yang bersangkutan atau Ketua Majelis Hakim yang telah ditunjuk memeriksa perkara tersebut, menetapkan hari sidang dan memerintahkan memanggil kedua belah pihak supaya hadir pada persidangan yang ditetapkan itu, Jika perkara perdata tidak dapat diselesaikan secara damai, tahapan-tahapan pemeriksaannya di Pengadilan Negeri dapat digambarkan sebagai berikut (Syahrani, 2016: 29):

1) Penggugat mengajukan gugatan (dikepaniteraan, diproses)

2) Proses mediasi untuk mengusahakan perdamaian

3) Tergugat menyampaikan eksepsi/jawaban

4) Penggugat menyampaikan replik

5) Tergugat menyampaikan duplik

6) Penggugat dan tergugat menyampaikan alat-alat bukti

7) Penggugat dan tergugat menyampaikan tanggapan terhadap alat bukti yang diajukan pihak lawan

8) Penggugat dan tergugat menyampaikan kesimpulan

9) Hakim membacakan putusan

\subsection{Asas Sederhana, Cepat, Dan Biaya Ringan Dalam e-Court}

Peraturan Mahkamah Agung (PERMA) Nomor 1 Tahun 2019 tentang Administrasi Perkara Dan Persidangan Di Pengadilan Secara Elektronik merupakan peraturan yang dibuat guna memenuhi ketentuan Pasal 2 ayat (4) Undang-Undang Nomor 48 Tahun 2009 
tentang Kekuasaan Kehakiman menyebutkan peradilan dilakukan dengan sederhana, cepat dan biaya ringan, maka perlu dilakukan pembaruan administrasi dan persidangan guna mengatasi kendala dan hambatan dalam proses penyelenggaraan peradilan. Tuntutan perkembangan zaman juga mengharuskan adanya pelayanan administrasi perkara dan persidangan di pengadilan lebih efektif dan efisien. Hal-hal yang terdapat dalam $e$-Court juga menciptakan proses penyelenggaraan peradilan yang transparan adanya e-Skum dimana proses biaya dalam berperkara jelas dan sesuai ketentuan yang berlaku.

Dalam pelaksanaannya di peradilan Indonesia asas sederhana yang berarti acara yang jelas, mudah dipahami dan tidak berbelit-belit selalu mengalami perkembangan dalam pelaksanaannya, dengan terciptanya e-Court dimana beracara di pengadilan menjadi lebih sederhana hanya memerlukan koneksi internet dan formalitas di muka pengadilan tidak diperlukan terlalu banyak sehingga mengurangi keengganan atau ketakutan seseorang untuk beracara di muka pengadilan. Kata cepat yang mengacu pada jalannya persidangan juga terdapat dalam pelaksanaan $e$-Court yaitu setiap proses persidangan dari pendaftaran hingga hasil putusan kecuali dalam hal pembuktian yang memerlukan para pihak untuk bertemu di muka pengadilan yang dapat dilaksanakan dalam hitungan menit karena proses sidang dalam $e$-Court berupa file atau dokumen yang diupload kedalam aplikasi website atau sistem $e$-Court sehingga suatu persidangan sukar untuk mengalami penundaan hingga bertahun-tahun karena saksi tidak datang. Biaya ringan agar terpikul oleh rakyat juga terlaksana dalam $e$-Court ditambah trasnsparasi dan kejelasan biaya dalam proses $e$-Court dengan adanya rincian biaya yang harus dibayarkan lewat transfer bank menambah kepercayaan masyarakat untuk mengajukan perkara ke pengadilan. Terpenuhinya asas tersebut membuat terjaminnya kemanfaatan hukum bagi para pihak yang jelas dan mampu mengikuti perkembangan zaman.

\subsection{Asas Manfaat Dalam Pengadilan Elektronik (e-Court)}

Penggunaan $e$-Court di daerah perkotaan dengan tingkat banyaknya masyarakat yang hidup modern menjadikan e-Court lebih bermanfaat karena setiap hak/tuntutan yang diajukan oleh pihak yang berperkara dan menggunakan kuasa hukum dalam penyelesaiannya maka $e$-Court dapat menghemat waktu dan mempercepat proses selesainya suatu kasus dan dapat dilakukan dalam waktu yang bersamaan karena semua kegiatan $e$ Court berlangsung tanpa harus hadir di pengadilan dan tatap muka langsung. Namun untuk masyarakat pedesaan e-Court tidak terlalu berdampak terhadap masyarakat yang masih memerlukan keadilan yang dilakukan secara adat dimana nilai keadilan dipandang lebih baik saat suatu hak/tuntutan dapat dilaksanakan sesuai kebiasaan yang masih alami dan bertatap muka antar pihak yang berperkara.

Kemudian dengan $e$-Court para pencari keadilan dijamin kejelasannya dalam hal biaya perkara tanpa harus mengeluarkan biaya yang diluar diterbitkannya nomer virtual account (nomer pembayaran biaya perkara) sehingga dalam e-Court para pencari keadilan dapat fokus untuk mendapatkan keadilan yang dikehendaki, hasil putusan yang dapat diakses setiap waktu karena berbentuk softfile memudahkan untuk disimpan dan dilihat dimana saja dengan adanya perangkat elektronik untuk mengaksesnya. Namun hal tersebut tidak dapat dilakukan jika koneksi internet tidak baik apalagi jika masih ada daerah yang tidak terjangkau internet maka pengadilan secara konvensional lebih utama daripada $e$-Court.

\subsection{Peran Kuasa Hukum Dalam Pengadilan Elektronik (e-Court)}

Adanya pembagian golongan yang berlangsung sejak kolonial Belanda yang masih berlaku sampai sekarang membuat Peraturan Mahkamah Agung (PERMA) Nomor 1 Tahun 2019 tentang Administrasi Perkara Dan Persidangan Di Pengadilan Secara Elektronik bagi 
golongan hukum adat dengan kurangnya pengetahuan tentang Information Technology (IT) serta kurangnya akses internet yang memadai membuat setiap orang yang berperkara belum bisa menerapkan pengadilan elektronik (e-Court) ini dan masih memerlukan pengadilan konvensional. Pelaksanaan beracara perkara perdata di muka pengadilan menggunanakan kuasa dan tanpa kuasa juga merupakan hal yang telah berlangsung sejak lama dimana hukum beracara perdata di pengadilan digolongan menggunakan HIR/RBg dan $\mathrm{Rv}$, golongan yang menggunakan $\mathrm{HIR} / \mathrm{RBg}$ termasuk didalamnya golongan pribumi saat beracara di muka pengadilan tidak diwajibkan untuk diwakilkan menggunakan kuasa hal ini dikarenakan penduduk golongan pribumi ketika itu kebanyakan buta huruf dan awam hukum (Sunarto, 2016: 253). Berbeda dengan golongan yang menggunakan Rv yang didalamnya termasuk warga negara Eropa diwajibkan untuk menggunakan kuasa dikarenakan golongan mereka dipandang sudah memiliki wawasan yang lebih luas dan warga golongan Eropa sudah mengenal pendidikan sehingga memiliki pemikiran dan sikap lebih maju dan mampu mengikuti perkembangan terutama dalam hal hukum, sehingga munculnya $e$-Court mengharuskan kuasa hukum untuk mempelajari perkembangan ilmu hukum mengikuti perkembangan masyarakat.

Dalam perkara perdata inisiatif (permulaan) untuk mengajukan tuntutan hak dalam hukum acara perdata sepenuhnya diserahkan kepada pihak yang merasa dirugikan atau yang berkepentingan dan ada tidaknya perkara di pengadilan tergantung pihak yang berkepentingan, sedangkan dalam pelaksanaan tidak semua pihak yang merasa dirugikan mampu atau mengerti cara mengajukan tuntutan hak ke pengadilan oleh karena itu sistem hukum acara perdata pihak yang merasa dirugikan atau yang akan mengajukan gugatan ke pengadilan dapat dibantu atau diwakili oleh seorang kuasa hukum. Kuasa hukum dalam perwakilannya di pengadilan dapat dikatakan untuk mewakili dengan pertimbangan bahwa suatu proses pengadilan memerlukan pengetahuan hukum dan cakap teknis agar persidangan dapat berjalan lancar dan putusan dijatuhkan seadil-adilnya. Adanya administrasi perkara dan persidangan di pengadilan secara elektronik maka seorang kuasa hukum harus mampu memahami tentang langkah-langkah menggunakan aplikasi berbasis website e-Court yang disediakan oleh Mahkamah Agung karena prosesnya yang berkesinambungan dari proses pendaftaran hingga putusan dan sangat perlu diperhatikan bahwa email yang terdaftar pada awal pendaftaran pengguna akan digunakan sepanjang beracara menggunakan $e$-Court untuk diperiksa pemberitahuan email masuk sehingga dapat mengikuti dan memahami proses selanjutnya selama $e$-Court masih berjalan karena segala pemberitahuan mengenai proses e-Court diperoleh melalui pemberitahuan lewat email terdaftar, hal ini membuat seseorang yang mengajukan gugatannya melalui $e$-Court harus memahami proses pengadilan menggunakan e-Court dengan baik dan saat seseorang menggunakan bantuan kuasa hukum tentu mengharuskan seorang kuasa hukum untuk lebih mengetahui dan memahami proses persidangan $e$-Court lebih baik daripada seseorang yang dibantunya. Sebelum proses persidangan dimulai, dalam e-Court diwajibkan bahwa pihak lawan harus bersedia juga untuk menggunakan $e$-Court yang dibuktikan dengan form persetujuan prinsipal oleh karena itu penggunaan e-Court akan terhambat atau kurang efektif saat pihak lawan tidak bersedia menggunakan $e$-Court. E-Court dapat diakses hanya menggunakan internet sehingga penggunaannya di daerah dengan akses internet kurang dan daerah dengan persebaran informasi yang lambat dapat menghambat jalan dan proses tersebarnya serta pemahaman seseorang mengenai $e$-Court.

\subsection{Dualisme Pengadilan Elektronik (e-Court)}

Pengajuan perkara yang akan diselesaikan menggunakan e-Court mengharuskan menggunakan persetujuan kedua belah pihak yang berperkara, sehingga saat salah satu 
pihak tidak menghendaki bersidang menggunakan e-Court maka persidangan diadakan menggunakan pengadilan konvensional. Walaupun akses $e$-Court yang tidak terbatas waktu karena semua kegiatannya bisa dilakukan kapanpun dan dimanapun asalkan ada jaringan internet, namun seluruh kegiatan e-Court hanya diakui jika prosesnya terjadi saat jam kerja pengadilan secara konvensional jika kegiatannya dilakukan diluar jam kerja pengadilan diluar jam kerja resmi maka dihitung efektif pada hari kerja selanjutnya.

Persidangan secara elektronik (e-Litigation) dilaksanakan atas persetujuan penggugat dan tergugat setelah proses mediasi dinyatakan tidak berhasil, dalam e-Court sidang pembuktian dilaksanakan sesuai hukum acara yang berlaku dengan demikian dalam hal sidang pembuktian membutuhkan keadaan yang mengharuskan dibuktikan secara langsung maka para pihak dalam membuktikan akan dilakukan dengan memanggilnya untuk hadir secara langsung ke pengadilan dan melaksanakan sidang pembuktian di pengadilan konvensional.

\section{Kesimpulan}

Kesimpulan yang dapat diambil dari pembahasan bahwa Bahwa adanya pengadilan secara elektronik (e-Court) dapat memberikan asas kemanfaatan bagi para pihak meliputi transparasi proses, biaya, dan efisiensi waktu bagi para pencari keadilan yang mampu mengakses IT (Information Technology) serta adanya dualisme masih dibutuhkan bagi para pencari keadilan yang masih membutuhkan beracara secara konvensional karena keterbatasan mengakses IT (Information Technology).

\section{Daftar Referensi}

\section{Jurnal}

Lumbanraja, A. D. (2020). Perkembangan Regulasi dan Pelaksanaan Persidangan online Di Indonesia dan Amerika Serikat Selama Pandemi Covid-19. Jurnal Crepido, 02(01), 46-58.

Retnaningsih, S., Nasution, D. L. S., Velentina, R. A., Manthovani, K. (2020). Pelaksanaan ECourt Menurut Perma Nomor 3 Tahun 2018 Tentang Administrasi Perkara Di Pengadilan Secara Elektronik dan E-Litigation Menurut Perma Nomor 1 Tahun 2019 Tentang Administrasi Perkara dan Persidangan Di Pengadilan Secara Elektronik (Studi Di Peng. Jurnal Hukum E Pembangunan, 50(1), 124-144. https:// doi.org/10.21143/jhp.vol50.no1.2486

Sudarsono. (2019). Konsep Peradilan Secara Elektronik Di Lingkungan Peradilan Tata Usaha Negara. Tanjungpura Law Journal, 3(1), 42-64.

Sunarto. (2016). Prinsip Hakim Aktif Dalam Perkara Perdata. Jurnal Hukum Dan Peradilan, 5(2), 249-276. https://doi.org/10.25216/jhp.5.2.2016.249-276

Wantu, F. M. (2012). Mewujudkan Kepastian Hukum, Keadilan Dan Kemanfaatan Dalam Putusan Hakim Di Peradilan Perdata. Jurnal Dinamika Hukum, 12(3), 481-489. http://dinamikahukum.fh.unsoed.ac.id/index.php/JDH/article/view/121/68

Wijayanta, T. (2014). Asas Kepastian Hukum, Keadilan dan Kemanfaatan dalam Kaitannya dengan Putusan Kepailitan Pengadilan Niaga. Jurnal Dinamika Hukum, 14(2), 216-226. https:// doi.org/10.20884/1.jdh.2014.14.2.291 


\section{Buku}

Ali, Z. (2016). Metode Penelitian Hukum. Jakarta: Sinar Grafika.

Fakhriah, E. L. (2019). Kapita Selekta Hukum Acara Perdata Indonesia. Bandung: Mandar Maju.

Syahrani, R. (2016). Sistem Peradilan dan Hukum Acara Perdata di Indonesia. Bandung: Citra Aditya Bakti.

\section{Online/World Wide Web}

Mahkama Agung RI. (n.d.). e-Court Mahkamah Agung RI. Retrieved October 11, 2019, from https://ecourt.mahkamahagung.go.id

Pengadilan Negeri Ungaran. (n.d.). Prosedur Perkara Perdata. Retrieved January 10, 2020, from http://pn-ungaran.go.id/home/index.php/prosedur-perkara/prosedur-perkaraperdata/254-pengajuan-gugatan 